Nikita Vladimirovich Mkrtchyan,

Candidate of Geography,

Leading Researcher

of the Institute of Demography

of theNational Research University

Higher School of Economics

Moscow, Russia

nmkrtchyan@hse.ru

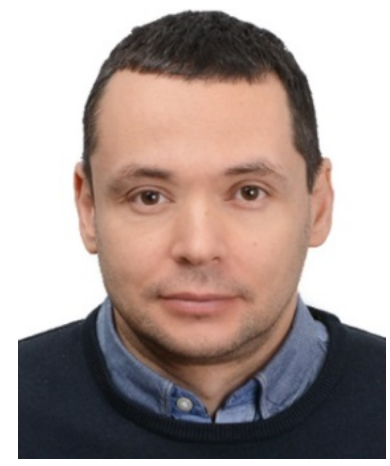

DOI 10.31554/978-5-7925-0571-1-2019-2-117-124

\title{
MIGRATION AND SUBURBANIZATION IN THE RUSSIAN REGIONAL CAPITALS AND THEIR SUBURB
}

Regional capitals, represented in Russia almost exclusively by large cities and their surburbs are centers of migration attraction of the population. According to the calculations made on the basis of the database MED (Rosstat) for 2012-2016, the suburban areas are ahead of the capitals in terms of migration growth rates. In fact, suburban areas are the class of territories leading in this indicator in Russia. Data on intra-regional migration in 39 regions of Russia, collected at a special request from the territorial authorities of Rosstat, showed that in the vast majority of regions, suburbs pull the population of near regional centers, that can be considered as a clear sign of the beginning of suburbanization in Russia. The annual total migration flow of the population from regional capitals to the suburbs is approximately 40-50 thousand people, which is almost twice the migration growth of the population of the Krasnodar territory due to internal Russian migration.

Keywords: regional centers, surburb, migration, suburbanization, Russia.

The resumption of strong population growth in Russian major cities as a result of migration after a break in the 1990s, associated with the transformational crisis, once again reminded of the stadiality of urbanization processes and the degree of its completion/incompleteness in the country [Nefedova, Treyvish 2002]. To what extent does the growth of large cities extend to surrounding areas (the suburbs, suburbia) - to answer this question we will analyze role of the individual streams of migration in the population dynamics and its structure in the capitals of the regions of Russia and their suburban areas. 
The considerable experience gained by investigators in Western Europe and the USA in studying the dynamics of the population of large cities and their suburbs, the variety of sources of statistical information on migration processes in these territories allowed us to go on to study the structural characteristics of the popullation of suburbs [Wulff, Lobo 2009], the features of the natural population movement and etc. The structural features of the population growth of cities and their suburbs were studied with a certain lag in the post-socialist countries of Eastern Europe, including on the example of the capitals of countries or individual major agglomerations [Kure, Wojtowicz, Galka 2015; Ouředníček 2007]. In these countries suburbanization processes, expressed in faster growth of the suburbs of large cities with the stagnation of large cities (centers), were surely marked by researchers already in the 1990s. [Sander 2014; Tammaru, Kulu, Kask 2004]. In the post-Soviet countries the development of suburbanization process was delayed, there was incompleteness of the Russian urbanization [Nefedova, Pokrovsky, Treyvish 2015]. Large cities were growing more confidently [Karachurina, Mkrtchyan 2013; Makhrova, Kirillov 2014], regional capitals demonstrated an overwhelming population growth (in the vast majority cities with a population of more than 200 thousand people) [Karachurina 2018]. Unlike other countries the processes of suburbanization in Russia weren't studied enough, a comprehensive study the suburbs in recent years were carried out in Moscow [Makhrova, Nefedova, Treyvish 2008; Ioffe, Zayonchkovskaya 2011], Irkutsk [Grigorichev 2013, 2017; Emelyanova, Serebrennikov 2016] agglomerations, in and around Ulan-Ude [Breslavsky 2014]. According to their results, the growth of the suburban population is associated both with the expansion of cities beyond their administrative borders and with the inflow of migrants from the intraregional periphery to the surburbs, the construction of cottage villages in suburbia where residents of agglomeration centers resettle. It is in the latter case that we deal with classical suburbanization, which has long been observed in many developed countries [Rérat 2012]. Another sign of suburbanization is the growth of suburbs due to the relocation of residents of the agglomeration center, which is also observed in the west, and with a certain lag of delay in post-socialist countries [Sander 2014; Gnatiuk 2016].

Data and used methods. The calculations are based on official statistics on the number and migration of the population at the level of urban districts and municipal districts (Database of indicators of municipalities - DB SW) for 72 regions of Russia. With the exception of the most general data, 
Moscow, St. Petersburg, the Moscow and Leningrad regions were not taken into account in analysis, which, due to the size and structural heterogeneity of the suburbs, deserve separate consideration as well as a number of regions for which information is not presented in the DB SW. Also, data of intra-regional migration is used (form t_pt2n) on 39 regions, getting of Rosstat territorial bodies on request. The suburbs of the regional capitals are identified on the basis of the author's methodology, which was tested in a number of publications [Mkrtchyan 2017; 2018]. To the suburbs(suburban areas) we include municipal entities that have a considerable length of border with the territory of the urban district, in which territory the capital of the region is located.They can consist either of one or several municipalities, the larger the regional capital, usually the larger its suburbs.

Results and its discussion. As previous calculations showed [Mkrtchyan 2017; 2018], on average, the population in the suburbs has been growing faster than in the regional centers in recent years. In terms of the rate of migration growth in recent years the suburbs are ahead of regional capitals (table 1).

Table 1

Components of changes in the population of the considered regions*,

2012-2016, per 1000

\begin{tabular}{|l|c|c|c|c|}
\hline & $\begin{array}{c}\text { Total } \\
\text { increase }\end{array}$ & $\begin{array}{c}\text { Natural } \\
\text { growth }\end{array}$ & $\begin{array}{c}\text { Migration } \\
\text { growth }\end{array}$ & ATP \\
\hline $\begin{array}{l}\text { All population of the } \\
\text { considered regions, } \\
\text { including: }\end{array}$ & $-0,3$ & $-0,4$ & 0,1 & 0,0 \\
\hline $\begin{array}{l}\text { Capitals of regions } \\
\text { and capital territo- } \\
\text { ries, total }\end{array}$ & 7,5 & 1,2 & 6,3 & 0,0 \\
\hline $\begin{array}{l}\text { The capitals of the } \\
\text { regions }\end{array}$ & 7,2 & 1,4 & 5,8 & 0,1 \\
\hline Capital Territories & 8,7 & 0,5 & 8,2 & 0,4 \\
\hline Other territories & $-6,1$ & $-1,5$ & $-4,5$ & 0,0 \\
\hline
\end{tabular}

*excluding Moscow, St. Petersburg, Moscow and Leningrad regions, rep. Dagestan, Ingushetia and Tyva, Nenets and Chukotka Autonomous Okrug.

Source: Population and migration of the Russian Federation, statistical bulletins for 2013-2017 ; Rosstat, DB SW.

In 2012-2016 annual population growth of capitals and their suburbs due to migration on average was amounted to 307 thousand people (excluding 
Moscow, St. Petersburg and its regions), including 194 thousand due to domestic Russian migration and 113 thousand due to international migration. Herewith, the whole increase in domestic Russian migration was provided due to intra-regional movements, because from the regional capitals and metropolitan territories there was a small (about 14 thousand people annually) population outflow to Moscow, St. Petersburg and its regions.

Almost 3/4 of migration growth was accounted for regional capital, but its intensity was higher in the suburbs. Moreover, only intraregional migration provides differences in the intensity of inflow; the indicators of interregional and international migration are absolutely similar.

On the whole, the migration balance of large cities and its suburbs doesn't have a clearly defined regional specificity: the regional centers and their suburbs actively attracting migrants prevail in all parts of the country, which proves the widespread prevalence of the centripetal migration trend.

Intraregional migration- features of suburbanization. Regional capitals and their subrbs are the "operators" of a very big share of migration within the regions. The rapid growth of suburbs is in no small part due to migration from the cities around which they are formed. According to data from 39 regions of the Russian Federation intraregional migration "involving” regional capitals and their suburbs accounts 17.3 fixed by Rosstat long-term in-country migration and a third of intra-regional migration.

For suburbs the role of the regional capital in the migration turnover is especially large: in 2017, $45 \%$ of intra-Russian (both intra- and interregional) migrants arriving in the suburbs moved from the regional capital around which they are formed (table 2). In turn, $42 \%$ of Russian migrants leave the suburbs for the regional capital.

The largest regional capitals (listed in Table. 3) have the growth of intraregional migration, but still losing population in the exchange with their own suburbs. In total, out of 39 regions, more than $80 \%$ of the regional capitals lose their population in the migration exchange with the suburbs. In 2017 the migration growth of the suburbs of 38 regional capitals with its capitals reached 22.2 thousand people. If the data is distributed to the remaining regions, it turns out that the flow of people from the capitals in their suburbs, according to our estimates, is 40-50 thousand people annually, that exceeds the migration growth of St. Petersburg or almost twice - the Krasnodar Territory. It is the suburbs in many regions of Russia that are becoming territories experiencing migration growth with all municipalities of their region 
without exception. It can be unmistakable signs of suburbanization becoming more common in Russia in spite of the strong geographical variations.

Table 2

Distribution of long-term domestic Russian migrants in the capitals, suburbs and peripheral territories by directions of resettlement, 2017, \%

\begin{tabular}{|c|c|c|c|c|c|c|}
\hline \multirow[b]{2}{*}{ Arrived at: } & \multicolumn{6}{|c|}{ Where the migrants come from } \\
\hline & $\begin{array}{c}\text { from } \\
\text { other } \\
\text { regions }\end{array}$ & $\begin{array}{c}\text { from } \\
\text { the } \\
\text { same } \\
\text { MO }\end{array}$ & $\begin{array}{l}\text { from the } \\
\text { regional } \\
\text { capital }\end{array}$ & $\begin{array}{c}\text { from } \\
\text { the sub- } \\
\text { urbs of } \\
\text { RC }\end{array}$ & $\begin{array}{c}\text { from } \\
\text { periph } \\
\text { eral } \\
\text { MO }\end{array}$ & Total \\
\hline $\begin{array}{l}\text { Regional } \\
\text { capitals }\end{array}$ & 45,0 & 0,7 & 0,0 & 8,7 & 45,7 & 100,0 \\
\hline $\begin{array}{l}\text { suburbs of the } \\
\text { RC }\end{array}$ & 26,0 & 6,6 & 45,0 & 1,4 & 21,0 & 100,0 \\
\hline $\begin{array}{l}\text { peripheral } \\
\text { MO }\end{array}$ & 46,7 & 10,7 & 14,0 & 1,4 & 27,1 & 100,0 \\
\hline & \multicolumn{6}{|c|}{ Where migrants move } \\
\hline $\begin{array}{l}\text { Departed } \\
\text { from: }\end{array}$ & $\begin{array}{l}\text { to other } \\
\text { regions }\end{array}$ & $\begin{array}{l}\text { to the } \\
\text { same } \\
\text { MO }\end{array}$ & $\begin{array}{l}\text { to the } \\
\text { regional } \\
\text { capital }\end{array}$ & $\begin{array}{c}\text { To the } \\
\text { suburb } \\
\text { of the } \\
\text { RC }\end{array}$ & $\begin{array}{c}\text { To } \\
\text { periph } \\
\text { eral } \\
\text { MO }\end{array}$ & Total \\
\hline $\begin{array}{l}\text { Regional } \\
\text { capitals }\end{array}$ & 53,2 & 0,8 & 0,0 & 12,8 & 33,1 & 100,0 \\
\hline $\begin{array}{l}\text { Suburbs of } \\
\text { RC }\end{array}$ & 31,6 & 9,0 & 41,9 & 1,8 & 15,7 & 100,0 \\
\hline $\begin{array}{l}\text { peripheral } \\
\text { MO }\end{array}$ & 47,5 & 10,2 & 17,3 & 2,2 & 22,9 & 100,0 \\
\hline
\end{tabular}

Source: Rosstat, data for 39 regions received on request.

Not only regional capitals, but also second-order centers give its population to their surburbs. A similar picture is observed, for example, in Tolyatti, Nizhnekamsk, Naberezhnye Chelny, Stary Oskol, Sterlitamak, Magnitogorsk. We believe that suburbanization will cover an increasing share of urban agglomerations, that concentrate migration flows, both intra- and inter-regional.

Thus, the calculations show that in Russia in the 2010s the process of suburbanization got developed with a strong delay not only relative to the United States, Western countries, but also to many Eastern European coun- 
tries. However, the analysis of statistical data doesn't allow us to judge to what extent this process is associated with the development of suburbs in its classical sense - low-rise buildings and other signs of a specific suburban environment, but in which - the exit of cities beyond their administrative borders. The answer to these questions needs further research, including on selected regional cases.

Table 3

Migration increase / decrease in the population of certain regional capitals with a population of more than 1 million people, 2017 , people

\begin{tabular}{|l|l|l|l|l|l|l|}
\hline & Total & $\begin{array}{l}\text { Interre- } \\
\text { gional }\end{array}$ & $\begin{array}{l}\text { Intra- } \\
\text { regional }\end{array}$ & capital & $\begin{array}{l}\text { sub- } \\
\text { urb }\end{array}$ & $\begin{array}{l}\text { Other } \\
\text { MO }\end{array}$ \\
\hline Krasnodar & 11035 & 7262 & 3773 & - & -406 & 4179 \\
\hline Ufa & 1579 & -886 & 2465 & - & -2642 & 5107 \\
\hline Kazan & 3482 & 1799 & 1683 & - & -2952 & 4635 \\
\hline Perm & 2609 & -1417 & 4026 & - & -1079 & 5105 \\
\hline Samara & -5248 & -2168 & -3080 & - & -3147 & 67 \\
\hline Saratov & 1341 & -2050 & 3391 & - & -470 & 3861 \\
\hline $\begin{array}{l}\text { Chelya- } \\
\text { binsk }\end{array}$ & 355 & -2191 & 2546 & - & -901 & 3447 \\
\hline Omsk & -5827 & -7659 & 1832 & - & -192 & 2024 \\
\hline $\begin{array}{l}\text { Novosi- } \\
\text { birsk }\end{array}$ & 278 & 1616 & -1338 & - & -2322 & 984 \\
\hline $\begin{array}{l}\text { Krasno- } \\
\text { yarsk }\end{array}$ & 906 & -970 & 1876 & - & -1368 & 3244 \\
\hline \begin{tabular}{l} 
Total \\
\hline
\end{tabular} & 9326 & -7310 & 16636 & - & - & 11789 \\
\hline
\end{tabular}

Source: Rosstat, data for 39 regions received on request.

\section{References and sources}

Breslavsky A. S. Nezaplanirovanniye prigorody: selsko-gorodskaya migratsiya i rost Ulan-Ude $\mathrm{v}$ postsovetskiy period [Unplanned suburbs: rural-urban migration and the growth of Ulan-Ude in the post-Soviet period] / ed. by M. N. Baldano. Ulan-Ude: Publishing House of the BSC SB RAS, 2014. - 192 p.

Grigorichev K. V. V teni bolshogo goroda: sotsialnoye prostranstvo prigoroda [In the shadow of the big city: the social space of the suburbs]. - Irkutsk: Print, 2013. - 248 p. 
Grigorichev K. V. Subregionalniye migratsii i formirovaniye prigoroda sibirskogo goroda [Sub-regional migrations and formation of Siberian city suburbs] // Mir bolshogo Altaya [The world of big Altai]. - 2017. - №1(3). - P. 31-42.

Emelyanova N. V., Serebrennikov E.N. Sotsialno-demograficheskaya otsenka kachestva zhizni naseleniya Irkutskoy aglomeratsii [Socio-demographic assessment of the quality of population's life of Irkutsk agglomeration]// Vestnik Zabaikalskogo gosudarstvennogo universiteta [The Bulletin of Zabaikalsky State University]. 2016. - Vol. 22, № 6. - P. 96-107.

Karachurina L. B. Dinamika naseleniya regionalnykh tsentrov i vtorykh gorodov regionov v Rossii: proyavlyautsya li tendentsii k politsentrizmu? [Population dynamics of regional centers and second cities of regions in Russia: are there tendencies to polycentrism?] // Izvestiya RAN [News of RAS]. Ser. geogr . - 2018. - № 4. P. 7-21.

Karachurina L. B., Mkrtchyan N. V. Izmeneniya chislennosti naseleniya munitsipalnykh obrazovaniy RF (1989-2010): tsentro-periferiyniye vzaimodeystviya [Population change in municipalities of the Russian Federation (1989-2010): centerperipheral interactions] // Geografiya naseleniya i sotsialnaya geografiya [Population geography and social geography]. Voprosy geografii [Geography issues]. Ser. Voprosy geografii. Russkoye geograficheskoye obshchestvo ["Geography issues” Russian geographical society], Moscow branch. - M.: Kodex, 2013. - P. 82107.

Makhrova A. G., Kirillov P. L. "Zhilishchnaya proektsiya” sovremennoy rossiyskoy urbanizatsii ["The housing projection" of contemporary Russian urbanization] // Regionalniye issledovaniya [Regional study]. - 2014. - № 4. P. 134-144.

Makhrova A. G., Nefedova T. G., Treivish A. I. Moskovskaya oblast segodnya i zavtra: tendentsii i perspektivy prostranstvennogo razvitiya [Moscow region today and tomorrow: trends and prospects of spatial development]. - M.: Noviy khronograf [New chronograph], 2008. - 344 p.

Mkrtchyan N. V. Pristolichiye territorii Rossii: dinamika naseleniya i migratsionniy balans [Russian capital territories: population dynamics and migration balance] // Chto mi znaem o sovremennykh rossiyskikh prigorodakh? [What do we know about modern Russian suburbs?] / ed. by A. S. Breslavsky. - Ulan-Ude: Publishing House of the BSC SB RAS, 2017. - P. 26-36.

Mkrtchyan N. V. Regionalniye stolitsy i ikh prigorody: osobennosti migratsionnogo balansa [Regional capitals and their suburbs: peculiarities of migration balance] // Izvestiya RAN [News of RAS]. Seriya geograficheskaya [Geographical series]. - 2018.- № 6. - P. 26-38.

Nefedova T. G., Pokrovsky N. E., Treyvish A. I. Urbanizatsiya, dezurbanizatsiya i selsko-gorodskiye soobshchestva $\mathrm{v}$ usloviyakh rosta gorizontalnoy mobilnosti 
[Urbanization, deurbanization and rural-urban communities in the context of increasing horizontal mobility] // Sotsiologicheskiye issledovaniya [Sociological research]. - 2015. - № 12. - P. 60-69.

Nefedova T. G., Treyvish A. I. Teoriya "differentsialnoy urbanizatsii” i ierarkhiya gorodov v Rossii na rubezhe XXI v. [The theory of "differential urbanization" and the hierarchy of cities in Russia at the turn of the XXI century] // [Problems of urbanization at the turn of the centuries] / ex. ed. A. G. Makhrova. - Smolensk: Oykumena, 2002. - P. 71-86.

Gnatiuk O. Demographic dimension of suburbanization in Ukraine in the light of urban development theories // AUC Geographica [S.I.]. N 52(2). - P. 151-163.

Ioffe G., Zayonchkovskaya Zh. Spatial shifts in the population of Moscow region // Eurasian Geogr. Econ. - 2011. - N 52(4). - P. 543-566.

Kulu H., Boyle P.J High fertility in city suburbs: Compositional or contextual effects? // European Journal of Population. - 2009. - N 25(2). - P. 157-174.

Kurek S., Wojtowicz M., Galka J. The changing role of migration and natural increase in suburban population growth: The case of a non-capital post-socialist city (The Krakow Metropolitan Area, Poland) // Moravian Geographical Reports. 2015. - N 23(4). - P. 59-70.

Ouředníček M. Differential suburban development in the Prague urban region // Geografiska Annaler: Series B, Human Geography. - 2007. - N 89(2). - P. 111-126.

Rérat P. The New Demographic Growth of Cities: The Case of Reurbanisation in Switzerland // Urban Studies. - 2012. - N 49(5). - P. 1107-1125.

Sander N. Internal migration in Germany, 1995-2010: New insights into EastWest migration and re-urbanisation // Comparative Population Studies. - 2014. N 39(2). - P. 217-246.

Tammaru T., Kulu H., Kask I. Urbanization, Suburbanization, and Counterurbanization in Estonia // Eurasian Geography and Economics. - 2004. -N 45(3). P. 212-229.

Wulff M., Lobo M. The new gentrifiers: The role of households and migration in reshaping Melbourne's core and inner suburbs // Urban Policy and Research. - 2009. - N 27(3). - P. 315-331. 